\title{
Drill biopsy in the diagnosis of lung lesions
}

\author{
P SHATAPATHY, R C SAHOO, K M RAO, K V KRISHNAN, P V P RAU, \\ A PADHEE
}

From the Department of Cardiovascular and Thoracic Surgery, Kasturba Medical College Hospital, Manipal, Karnataka, India

ABSTRACT A high speed pneumatic drill was used to perform 190 percutaneous transthoracic biopsies in 161 patients. The resultant cores of tissue provided a definite diagnosis in 146 patients, giving a success rate of $90.7 \%$. Complications occurred in 58 patients, subcutaneous emphysema being the most common, though only seven patients required active treatment, giving a rate of $3.7 \%$ for important complications. One patient died within 24 hours of the biopsy procedure owing te asphyxia resulting from aspiration of the contents of an acutely dilated stomach. Our experience clearly establishes that the drill biopsy as used by us is simple and safe and can be carried out in aq outpatient department, yielding better overall results than any other procedure for closed biopsy ow the lung currently practised.

Chest radiography, bronchoscopy, and pulmonary function studies are helpful for detecting pulmonary and mediastinal abnormalities, but specific diagnosis often requires microbiological and histopathological examination of the affected tissue. There has thus been an increasing demand for lung biopsy procedures. With the development of a range of new biopsy instruments and advanced cytological techniques, procedures for closed biopsy of the lung have increasingly usurped the place of the open approach. In 1969 Steele and Winstanley ${ }^{1}$ claimed that closed lung biopsy using a high speed pneumatic drill yields, with a low incidence of complications, a larger sample for the pathologist and thereby enhances the diagnostic accuracy. Impressed by their results, we adopted pneumatic drill biopsy of the lung as a routine practice; this report presents an analysis of our nine years' experience of the method.

\section{Methods}

We used a closed biopsy procedure using a high speed pneumatic drill for all patients with lung lesions referred to our department from January 1978 to December 1986 in whom sputum examination, chest radiography, biochemical or serological studies, and

Address for reprint requests: Professor P Shatapathy, Department of Cardiovascular and Thoracic Surgery, Kasturba Medical College Hospital, Manipal-576119, Karnataka, India.

Accepted 6 April 1987 bronchoscopic (both rigid and fibreoptic) ino vestigations failed to provide a definite diagnosis. Ths absolute contraindications to choosing this technique of lung biopsy were: suspected vascular lesions, sus pected hydatid cyst or bulla, lesions situated ver $\$$ close to the mediastinal structures, and the presenc $\vec{E}$ of a bleeding diathesis. Patients with a solitary puB monary nodule were not subjected to drill biopsy un? less they refused to give consent for explorator thoracotomy, and those with extensive bilaterat lesions with very poor lung reserve were generally in? vestigated by open lung biopsy.

\section{THE INSTRUMENT}

The high speed biopsy drill (Down Surgical Ltd尺 Mitcham, England) consists of a trephine and a drilk The hollow steel trephine is $7.5 \mathrm{~cm}$ long with an exter nal diameter of $3 \mathrm{~mm}$ and an internal diameter of $2 \cdot 1 \mathrm{~mm}$. It has a right angle smooth cutting edge. The bore is rifled internally for $5 \mathrm{~mm}$ behind the cutting edge to guide the tissue into the lumen. This is fitted with a sharp pointed keyed stylet projecting $2.5 \mathrm{mr}$ beyond the end. The hub of the trephine is connected by a Luer fitting to the spindle of a small Desoutter pneumatic drill, which is driven by compressed ais from a cylinder fitted with a reducing valve and roo tates at a trigger controlled speed up to $15000 \mathrm{rev} / \mathrm{miñ}^{2}$ at a pressure of $7 \mathrm{~kg} \mathrm{~cm}$.

THE TECHNIQUE

The biopsy was performed under local anaesthesi with the patient in a supine, lateral, or occasionalle 
prone position, depending on the site of the lesion. The exact location of the lesion in the lung and its distance from the skin surface was assessed by posteroanterior and corresponding lateral radiographs of the chest. A small cruciate incision $(5 \times 5 \mathrm{~mm})$ was made on the skin after preparation and anaesthetic infiltration. The trephine, with the pointed stylet in place, was introduced through the skin incision until the parietal pleural layer was felt to be pierced. A skin guard was slid and secured on to the trephine before specimens of superficially located lesions were obtained. The position of the guard was adjusted on the trephine so that at least $2.5 \mathrm{~cm}$ of the trephine would pass into the area of the lung harbouring the lesion without boring through the lesion and endangering adjacent structures. Thereafter the patient was asked to hold his breath in inspiration while the stylet was removed and the trephine was connected to the pneumatic drill. The drill was then activated and the trephine was allowed to drill in quickly until the desired depth was reached or the guard came in contact with the chest wall. Usually we used a driving pressure of $3.5-4 \mathrm{~kg} / \mathrm{cm}^{2}$ in cases with localised radiodensities and of $5-5.5 \mathrm{~kg} / \mathrm{cm}^{2}$ in diffuse lesions. To retain the core of tissue in the trephine and retrieve it, the pneumatic drill was removed and a glass syringe, containing $5 \mathrm{ml}$ of normal saline, was connected to the trephine in the breath holding position. The trephine was then withdrawn gently and completely while suction was maintained on the syringe. A few more millilitres of saline were sucked into the syringe so that the core of the tissue reached the barrel of the syringe. The tissue sample was retrieved by disconnecting the piston from the barrel of the syringe (tumour tissue sinks in saline while normal lung tissue floats). The wound was dressed and the patient kept under observation for at least four hours to detect any possible complication. Chest radiographs were taken if there was a suspicion of serious complications such as pneumothorax or haemothorax or before the biopsy procedure was repeated. Most of the time the procedure was performed by residents under the supervision of a staff member.

\section{Results}

One hundred and sixty one patients had drill biopsy of their lung lesions during the nine years from January 1978 to December 1986 . The ages of the 27 female patients ranged from 7 to 72 years (mean 48.0 (SD 15.8)) and of the 134 male patients from 12 to 80 years (mean 54.2 (SD 13.6)). A definite histological diagnosis could be established in 146 out of the 161 cases, providing an overall success rate of $90.7 \%$. In 125 out of the 161 subjects $(77 \cdot 6 \%)$ sufficient representative tissue was obtained during the first pro- cedure. A repeat biopsy was performed in 29 of the 36 failed cases, seven patients having refused a second attempt. A positive histological diagnosis was made in 21 out of these 29 patients, giving a diagnosis specific success rate of $72.4 \%$ for the repeat biopsy procedure.

One hundred and twenty patients had unilateral lesions, and 88 of these had mass lesions $(\geqslant 5 \mathrm{~cm}$ diameter) on routine chest radiographs. The diagnostic yield in the latter category was $100 \%(86.4 \%$ on the first attempt). In the remaining 32 patients with unilateral disease the lesions measured less than $5 \mathrm{~cm}$ in diameter, the smallest being about $27 \mathrm{~mm}$. Twenty three out of these $32(71.9 \%)$ had a positive biopsy result.

Out of 41 subjects with bilateral lesion, 29 had diffuse opacities on the chest radiograph. A positive biopsy result was obtained in 25 of these 29 subjects $(86 \cdot 2 \%)$. The success rate for the first biopsy procedure in this subset was $69 \%$. The diagnostic yield in 12 subjects with bilateral lesions but with at least one area of radiodensity of $5 \mathrm{~cm}$ or more was $10 / 12$ $(83 \cdot 3 \%)$. A repeat biopsy gave a negative result in one subject and the other refused a second procedure.

The size of the biopsy specimen varied from $35 \times$ $2 \mathrm{~mm}$ cylinders of tissue to small fragments of 2-3 mm. Generally, the largest cylinders were obtained from solid peripheral lesions and from patients with dense parenchymal disease. The various diagnoses established by histopathological studies, and sometimes corroborated either by microbiological examination of the material obtained by pneumatic drill biopsy or by the response to treatment, are shown in table 1.

Complications (table 2) followed the drill biopsy procedures in 58 instances $(30.5 \%)$ but were important enough to warrant treatment in only seven $(3.7 \%)$. In the present series there was only one case of haemopneumothorax requiring tube drainage. This patient, with bilateral diffuse lung opacities, died within 24 hours as a result of asphyxia from aspiration of vomitus after developing acute dilatation of the stomach. Though this one death $(0.6 \%)$ cannot be directly ascribed to the biopsy procedure, it nevertheless resulted from development that occurred during the management of the biopsy related complication.

After the biopsy 13 patients $(6 \cdot 8 \%)$ developed pneumothorax, which was detected clinically and confirmed by chest radiograph, giving an incidence of $6.8 \%$ of the biopsy procedures. Seven of these 13 were from the category of unilateral mass lesions, two had coin lesions, three belonged to the bilateral diffuse group, and one came from the other bilateral subset, giving incidences of $7 \%, 5 \cdot 4 \%, 8 \cdot 3 \%$, and $7 \cdot 6 \%$ of the procedures in the respective groups. 
Table 1 Histopathological diagnoses in 146 patients

\begin{tabular}{|c|c|c|c|}
\hline Neoplasms & & $\begin{array}{l}\text { Non-neoplastic } \\
\text { parenchymal disorders }\end{array}$ & \\
\hline $\begin{array}{l}\text { Pulmonary carcinoma } \\
\text { Squamous cell } \\
\text { Anaplastic } \\
\text { Large cell } \\
\text { Adenocarcinoma } \\
\text { Bronchoalveolar cell } \\
\text { Metastatic } \\
\text { Mediastinal } \\
\text { Lymphoma } \\
\text { Thymoma } \\
\text { Dermoid }\end{array}$ & $\begin{array}{r}36 \\
27 \\
13 \\
14 \\
11^{*} \\
2^{*} \\
\\
3 \\
1 \\
1\end{array}$ & $\begin{array}{l}\text { Diffuse (bilateral) } \\
\text { Interstitial fibrosis } \\
\text { Tuberculosis } \\
\text { Necrotising alveolitis } \\
\text { with vasculitis } \\
\text { Localised } \\
\text { Infections: } \\
\text { Tuberculosis } \\
\text { (caseating granuloma) } \\
\text { Non-specific } \\
\text { pneumonitis } \\
\text { Abscess } \\
\text { Actinomycosis } \\
\text { Sclerosing granuloma }\end{array}$ & $\begin{array}{l}10 \\
3 \dagger\end{array}$ \\
\hline
\end{tabular}

*One patient with a secondary malignant neoplasm and all the subjects with bronchoalveolar cell carcinoma had bilateral diffuse lesions.

tOne patient had both bronchoalveolar cell carcinoma and pulmonary tuberculosis.

\section{Discussion}

Trephine biopsy was first described by Kirschner ${ }^{2}$ in 1935, though Deeley ${ }^{3}$ in 1960 first reported use of the pneumatic drill for biopsy of the lung parenchyma. In 1970 Shatapathy and Padamsingh (unpublished data) from Vellore in India reported their early experience with the pneumatic drill biopsy to the Association of Thoracic and Cardiovascular Surgeons of India; they established positive and accurate histopathological diagnosis in 10 of 11 patients without any major complications. That report encouraged us to adopt closed lung biopsy as our biopsy procedure of choice. The diagnostic yield of $90.7 \%$ in the present series is far superior to the $50 \%$ yield reported by Boylen et al, ${ }^{4}$ slightly better than the yield obtained by Steel and Winstanley ${ }^{1}$ and others, ${ }^{5-7}$ and similar to that of King and Coworkers, ${ }^{7}$ who conducted the procedure under fluoroscopic control. In the present series the procedure was performed virtually blindly after the

Table 2 Complications of the 190 procedures in 161 patients

\begin{tabular}{lll}
\hline Complication & $\begin{array}{l}\text { No } \\
(\%) \\
\text { of patients }\end{array}$ & $\begin{array}{l}\text { Complications } \\
\text { requiring } \\
\text { active treatment }\end{array}$ \\
\hline Subcutaneous emphysema*† ${ }^{*}+$ & $44(23 \cdot 2)$ & $0 \S$ \\
Blood streaked sputum & $13(6.8)$ & 0 \\
Pneumothorax & $13(6.8)$ & $6(3.2 \%)^{* *}$ \\
Haemopneumothorax & $1(0.5) \ddagger$ & $1(0.5 \%)^{* *}$ \\
Death & $1(0.6) \ddagger$ & - \\
Total & $58(30.5)$ & $7(3.7)$ \\
\hline
\end{tabular}

*All the patients with pneumothorax had subcutaneous emphysema in various degrees.

tIn seven cases it extended beyond the chest wall.

tLater died of asphyxia.

\$Disappeared within 72 hours in 37 cases.

**Intercostal drainage.
Shatapathy, Sahoo, Rao, Krishnan, Rau, Padhe $\overrightarrow{\mathrm{S}}$

Table 3 Comparison of histological yields and incidence of $\frac{9}{0}$ complications (percentage rates) in various trephine biopsy series

\begin{tabular}{|c|c|c|c|}
\hline Series & $\begin{array}{l}\text { Histological } \\
\text { yield }\end{array}$ & $\begin{array}{l}\text { Total } \\
\text { complications }\end{array}$ & $\begin{array}{l}\text { Important } \\
\text { complication. }\end{array}$ \\
\hline 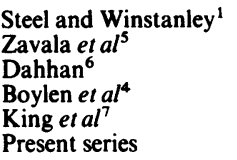 & $\begin{array}{l}85 \\
84 \\
70 \\
50 \\
89 \\
90 \cdot 7\end{array}$ & $\begin{array}{l}35 \\
40 \\
82 \\
37 \\
30 \cdot 5\end{array}$ & $\begin{array}{c}7 \cdot 1 \\
14 \\
12 \\
\frac{17}{37} \\
3 \cdot 7\end{array}$ \\
\hline
\end{tabular}

lesion had been localised on posteroanterior and lat $\overrightarrow{\vec{*}}$ eral radiographs. Besides the higher diagnostic yield心 we had a very low incidence of important compli cations $(3 \cdot 7 \%$-table 3$)$.

No biopsy procedure is absolutely safe. Open lung biopsy procedure may be associated with a fatality rate of over $30 \% .{ }^{8}$ Deaths have also been associate $\bar{\phi}$ with other procedures: $0 \cdot 1 \%$ for fine needle aspiration biopsy, ${ }^{9} 0.3 \%$ for bronchoscopic biopsy, ${ }^{10}$ and $0.1 \%$ for brush biopsy. ${ }^{11}$ Already 13 deaths have been re $\overrightarrow{0}$ ported with the use of various types of cutting needle for the biopsy procedure. ${ }^{12}$ The single death in ouf series is only indirectly attributable to the biopsy proo cedure.

Pneumothorax is the important non-fatal complio cation of closed lung biopsy. Its incidence for drim biopsy has been quoted as $26-65 \%,{ }^{13}$ while for needle biopsy it has ranged from zero ${ }^{14}$ to $57 \% .{ }^{15}$ In the present series significant pneumothorax requiring in 3 tercostal drainage followed $3.2 \%$ of procedures. Ou疋 overall incidence of pneumothorax, however, could. be much higher than the recorded figure of $6.8 \%$ be cause as an economy measure chest radiographs werf not routinely taken after the biopsy procedure and minor pneumothorax could well have escaped clinicas detection.

The $6.8 \%$ incidence of haemoptysis in the present series is within the reported range of this complication associated with needle biopsy procedures-from $1 \cdot 25 \%{ }^{14}$ to $10 \%$. $^{16}$

Other complications described in published report? are needle tract metastasis ${ }^{17}$; tumour cell dissem ination, converting an operable tumour into an iñ. operable one ${ }^{18}$; air embolism ${ }^{1920}$; anaphylactoi reaction $^{21}$; empyema and intralesional hae morrhage. ${ }^{22}$ This last complication is difficult to diage nose without exploration or serial chest radiograph $\$$ Air embolism or empyema has not occurred in the present series. Tumour cell dissemination has not been a concern to us, as patients suspected of having an operable malignancy have usually had explorator thoracotomy so that the diagnosis could be estab? lished and they could be offered definitive treatmen $\mathbb{R}$ Moreover, the danger of tumour spread along the 
Table 4 Range of diagnostic yield: various biopsy procedures

\begin{tabular}{|c|c|c|}
\hline Type of biopsy & Minimum yield & Maximum yield \\
\hline $\begin{array}{l}\text { Open lung biopsy } \\
\text { Other cutting }\end{array}$ & $50 \%$, Theodos ${ }^{24}$ & $100 \%$, Early et al ${ }^{25}$ \\
\hline needle biopsy & $53 \%$, Burt et al ${ }^{26}$ & $\begin{array}{l}\text { 83.9\%, McEvoy } \\
\text { et al }^{12}\end{array}$ \\
\hline $\begin{array}{l}\text { Transbronchial } \\
\text { biopsy }\end{array}$ & $\begin{array}{l}52 \% \text {, Wightman and } \\
\text { Douglas }^{27}\end{array}$ & $83 \%$, Khan $e t a l^{28}$ \\
\hline $\begin{array}{l}\text { Fine needle } \\
\text { aspiration biopsy } \\
\text { Pneumatic drill }\end{array}$ & $\begin{array}{l}29 \%, \text { Burt et al }{ }^{26} \\
50 \% \text {, Boylen et al }\end{array}$ & $\begin{array}{l}96 \% \text {, Sagel } \text { et } a l^{29} \\
90 \cdot 7 \% \text {, present series }\end{array}$ \\
\hline
\end{tabular}

needle tract has perhaps been overemphasised; Lauby et $a^{23}$ encountered no such case of tumour implantation after 621 procedures performed over 21 years.

As shown in table 4 , diagnosis in $100 \%$ of patients may be achievable only by an open lung biopsy procedure, but this is associated with a longer hospital stay and a high mortality rate, and is unsuitable for smaller hospitals. The $96 \%$ diagnostic yield of fine needle aspiration biopsy in Sagel's series ${ }^{29}$ has to be viewed in the perspective that, out of his 1211 patients, 896 had intrathoracic malignant lesions and the pathological report in most of those cases simply read "malignant cells present." Besides, the degree of discordance, ranging from $23 \%^{30}$ to $43 \%$, ${ }^{31}$ between the tumour classification based on the aspiration technique and that based on follow up histopathological study detracts from the merit of the needle aspiration biopsy. Pneumatic drill biopsy provides sufficient tissue for an accurate histopathological evaluation and virtually eliminates this problem. Further, Sooby et $a^{32}$ pointed out that, while conducting a bronchial biopsy procedure under fluoroscopic control, the performer had an average exposure of $12 \mathrm{mr}$ to the eyes and $27 \mathrm{mr}$ to the dominant hand. Our reliance only on posteroanterior and lateral chest radiographs for deciding on the site of biopsy therefore not only avoids this risk of exposure to radiation but also yields a diagnosis specific success rate similar to (table 5) if not better than those obtained under biplane image intensifier fluoroscopy ${ }^{12}$ and under computed tomographic guidance. ${ }^{29}$

We conclude that the high speed pneumatic drill biopsy procedure, as used by us, is simple, can be carried out in an outpatient department, provides a very high specific diagnostic rate with a very low incidence of important complications, and has scope for further increase in its diagnostic yield if additional emphasis is placed on cytological study of the biopsy specimens.

We thank Mr M Ganapathi Nayak for typing this manuscript.

\section{References}

1 Steele SJ, Winstanley DP. Trephine biopsy of lung and pleura. Thorax 1969;24:576-84.

2 Kirschner. Die Probebohrung. Schweiz Med Wochenschr 1935;65:28.

3 Deeley TJ. Drill biopsy: results with a high speed pneumatic drill. Acta Un Int Cancer 1960;16:338-40.

4 Boylen CT, Johnson NR, Richters V, Balchum OJ. High speed trephine lung biopsy: methods and results. Chest 1973;63:59-62.

5 Zavala DC, Bedell GN, Rossi NP. Trephine lung biopsy with a high speed air drill. $J$ Thorac Cardiovasc Surg 1972;64:220-8.

6 Dahhan A. Drill lung biopsy (letter). JAMA 1973; 224:904.

7 King EG, Bachynski JE, Mielke B. Percutaneous trephine lung biopsy. Chest 1976;70:212-6.

8 Jaffe JP, Maki DG. Lung biopsy in immunocompromised patients: one institution's experience and an approach to management of pulmonary disease in the compromised host. Cancer 1981;48: 1144-53.

9 Herman PG, Hessell SJ. The diagnostic accuracy and complications of closed lung biopsies. Radiology 1977;125:11-4.

10 Anderson HA. Transbronchoscopic lung biopsy for diffuse pulmonary disease. Chest 1978;73:734.

11 Finley R, Kieff E, Thomsen S, et al. Bronchial brushing in the diagnosis of pulmonary disease in patients at risk for opportunistic infection. Am Rev Respir Dis 1974;109:379-87.

12 McEvoy RD, Begley MD, Antic RAL. Percutaneous biopsy of intrapulmonary mass lesions. Cancer 1983; 51:2321-6.

13 Fraser RG, Pare JAP. Diagnosis of Diseases of the Chest Vol-I WB Saunders Company, Philadelphia, PA. 1977:249.

Table 5 Comparison of best results (percentage rates): various biopsy procedures

\begin{tabular}{|c|c|c|c|c|}
\hline Biopsy procedure & Reference & Diagnosis & Complications & Important complications \\
\hline $\begin{array}{l}\text { Open lung biopsy } \\
\text { Transbronchial biopsy } \\
\text { Trucut needle biopsy } \\
\text { Fine needle aspiration biopsy } \\
\text { Pneumatic drill }\end{array}$ & $\begin{array}{l}\text { Early et } a l^{25} \\
\text { Khan } \text { et } a l^{28} \\
\text { McEvoy } \text { et } a l^{12} \\
\text { Sagel } \text { et } a l^{29} \\
\text { Present series }\end{array}$ & $\begin{array}{l}100 \\
83 \\
83 \cdot 9 \\
96 \\
90 \cdot 7\end{array}$ & $\begin{array}{l}23 \\
12 \cdot 5 \\
21 \\
34 \cdot 6 \\
30 \cdot 5\end{array}$ & $\begin{array}{l}5 \cdot 7 \\
0 \\
3 \cdot 5 \\
14 \cdot 4 \\
3 \cdot 7\end{array}$ \\
\hline
\end{tabular}


14 Castelain G, Castelain C, et Pretet S. La ponction transparietale en pneumonologic. J Franc Med Chir Thorac 1971;25:91.

15 Fontana R, Miller WE, Beabout JW, Payne WS, Harrison EG. Transthoracic needle aspiration of discrete pulmonary lesions. Experience in 100 cases. Med Clin North Am 1970;54:961-71.

16 Lalli AF, Naylor B, Whitehouse WM. Aspiration biopsy of thoracic lesions. Thorax 1967;22:404-7.

17 Wilson JR, Joness RL, Mielke B, King EG. Trephine lung biopsy. Can Med Assoc J 1973;108:704-9.

18 Berger RL, Dargan EL, Huang BL. Dissemination of cancer cells by needle biopsy of the lung. $J$ Thorac Cardiovasc Surg 1972;63:430-32.

19 Jameson JB. Aspiration biopsy of localised intrathoracic lesions. Australas Radiol 1970;14:40-5.

20 Westcott JL. Air embolism complicating percutaneous needle biopsy of the lung. Chest 1973;63:108-10.

21 Stamfel G. Anaphylactoid reaction-a rare complication after fine needle aspiration biopsy of the lung [author's translation from German]. Radiologe 1982;22:329-30.

22 Sinner WN. Complications of percutaneous transthoracic needle aspiration biopsy. Acta Radiol 1976;17:813-28.

23 Lauby VW, Burnett WE, Rosemond GP, Tyson RR. Value and risk of biopsy of pulmonary lesions by needle aspiration. J Thorac Cardiovasc Surg 1965; 49:159-72.

24 Theodos PA. Lung biopsy in the diagnosis of pneu-
Shatapathy, Sahoo, Rao, Krishnan, Rau, Padhe $\overrightarrow{\overline{\vec{E}}}$ moconioses. Dis Chest 1968;53:271-81.

25 Early GL, Williams TE, Kilman JW. Open lung biopsȳㅡ Its effects on therapy in paediatric patient. Chesen 1985;87:467-9.

26 Burt ME, Flye MW, Webber BL, Wesley RA. Prospec tive evaluation of aspiration needle, cutting needleş transbronchial and open lung biopsy in patients with pulmonary infiltrates. Ann Thorac Surg 1981;32: 146-53.

27 Wightman AJA, Douglas AC. Fluroscopically con尺 trolled transbronchial biopsy of solitary periphera伩 pulmonary lesions using the fibreoptic bronchoscope Clin Radiol 1978;29:621-4.

28 Khan MA, Corona F, Masson RG, Whitcomb METransbronchial lung biopsy for sarcoidosis (letter). No Engl J Med 1976;295:225.

29 Sagel SS, Ferguson TB, Forrest JV, Roper CL, Weldor CS, Clark RE. Percutaneous transthoracic aspiration needle biopsy. Ann Thorac Surg 1978;26:399-405.

30 Steele JD. The solitary pulmonary nodule. J Thora民 Cardiovasc Surg 1963;46:21-39.

31 Stringfield JT, Markowitz DJ, Bentz RR, Welch MH予 Weg JG. The effect of tumour size and location of diagnosis by fibreoptic bronchoscopy. Chest 1977;72474-6.

32 Sooby DL, Jackson HL, Sandrock AR, Rich RD. Radiation exposure to radiologists during bronchial brustp biopsies. Radiology 1973;107:305-7. 


\section{References}

1 Harding A. Differential diagnosis and investigation. In: Harding A, ed. The hereditary ataxias and related disorders. London: Churchill Livingstone, 1984:205-13.

2 Allen SM, Hunt B, Green M. Fall in vital capacity with posture. Br J Dis Chest 1985;79:267-71.

3 Newsom Davis J, Goldman M, Loh L. Diaphragm function and alveolar hypoventilation. $Q J$ Med 1976;45:87-100.

4 Miller J, Moxham J, Green M. The maximal sniff in the assessment of diaphragm function in man. Clin Sci 1985;69:91-6.

5 Mier A, Brophy C, Moxham J, Green M. Phrenic nerve stimulation-normal values for twitch Pdi. Clin Sci 1986;70:70.

6 Newsom Davis J. Phrenic nerve conduction time in man. J Neurol Neurosurg Psychiatry 1967;30:420-6.

7 Agostoni E, Sant'Ambrogio G. The diaphragm. In: Campbell EJM, Agostoni E, Newson Davis J, eds. The respiratory muscles. London: Lloyd-Luke, 1970;145-60.

\section{Book notices}

Surgical Pathology of Diffuse Infiltrative Lung. A Flint, TV Colby. (Pp 234; \$49.50.) Orlando: Grune and Stratton, 1987. ISBN 0-8089-1867-2.

Now that relatively safe and non-invasive methods of biopsy are available, a firm diagnosis can be made in many cases of diffuse lung disease. At the same time histopathologists are increasingly faced with a bewildering range of changes, often in tiny samples of tissue. This book deals specifically with the pathology of disorders characterised by diffuse infiltration of the lung parenchyma-disorders which are frequently investigated by transbronchial, needle, or open biopsy. In the opening chapter the general principles of processing and interpretation are covered, and there is a short but highly relevant section on the "abnormal, non-diagnostic" specimen. The second chapter is devoted to infective processes, with emphasis on viral and fungal disease, tuberculosis, and pneumocystis pneumonia. Subsequent chapters deal with pulmonary eosinophilia, hypersensitivity pneumonitis and drug induced disease, diffuse alveolar damage, interstitial pneumonitis, vascular disease, and sarcoidosis. In the section on malignant neoplasms the emphasis is on diffuse infiltrative neoplasms, including lymphomas, metastatic disease, alveolar carcinoma, and Kaposi's sarcoma. The final chapter describes a miscellany of disorders such as histiocytosis $\mathrm{X}$, alveolar proteinosis, and amyloidosis. The text is well written and copiously illustrated by high quality photomicrographs. References are comprehensive and up to date. This book is not meant to be exhaustive. The authors have wisely omitted the exotic, concentrating instead on problems most commonly met with in contemporary practice. Inevitably, some topics could have been covered in more detail. Amiodarone toxicity, for instance, is dismissed in two sentences and one incomplete reference, and paraquat poisoning seems to have been forgotten. Nevertheless, this book ranks among the best of the currently available monographs on pulmonary pathology. Although primarily a bench guide for pathologists, it will also be a useful reference work for clinicians concerned with the management of chest disease-CWE.
Manual of Chest Medicine. JE Stark, JM Shneerson, T Higenbottam, CDR Flower. (Pp 256; £9.95.) Edinburgh: Churchill Livingstone, 1986. ISBN 0-443-02737-4.

This pocket manual has been written by a group of experienced Cambridge respiratory physicians with a radiological colleague, Dr CDR Flower. It is designed for the young doctor on a short term attachment to a respiratory unit and lays particular emphasis on dealing with practical problems. The first chapter covers a range of common respiratory symptoms and signs and is followed by a useful chapter on the radiology of the lung, including helpful comments about the place of specialist techniques such as computed tomography. A further chapter is devoted to respiratory function tests. Although simple tests are well described, the doctor working in a specialised unit might be helped by a fuller description of such "less widely available" tests as flowvolume loops and exercise testing. Subsequent chapters provide useful and often not readily obtained details of practical procedures. They deal concisely with the management of clinical problems and give useful practical hints, such as the need to alert the pathology laboratory of the arrival of samples from procedures such as transbronchial biopsy. Nearly all the clinical advice is very sound, as expected, though some would disagree with the statement that in Asian patients with suspected cervical tuberculosis aspiration or biopsy may be unnecessary. The chapter on pulmonary eosinophilia puts this disease spectrum into context with comments that the association with systematic vasculitis is very confusing, both in classification and in terminology - an observation which may take some time to dawn on the inexperienced doctor. This book will be particularly helpful to the junior doctor at senior house officer and registrar level. The senior registrar specialising in respiratory medicine may require additional detail.

\section{Notices}

\section{SEPCR meeting 1988}

The 23rd anilual meeting of SEPCR (Societas Europaea Physiologiae Clinicae Respiratoriae) will take place in Athens, Greece, on 20-24 June 1988. The topic will be respiratory failure. There will be invited lectures, free communications, seminars, and satellite symposia. Information from Dr NM Siafakas, 23rd Annual Congress of SEPCR, Organising Secretariat, 23 Asklipiou Street, PO Box 30365, 10680 Athens, Greece.

\section{Clinical respiratory physiology course}

A course on clinical respiratory physiology will be held at Hammersmith Hospital, London W12 0HS, on 15-18 March, 1988, for doctors and pulmonary function technicians, emphasising practical aspects and clinical applications. Details from the organisers (Drs JMB Hughes and Dr NB Pride, Department of Medicine).

\section{Correction}

\section{Drill biopsy in the diagnosis of lung lesions}

In the paper by Professor P Shatapathy and others (November 1987;42:858) line 3 of the second paragraph of column 2, p 858 , should read "The hollow Steel's trephine." 